\title{
Ethno-Religious Conflict and the Quest for Peace in a Plural Society in Africa
}

\author{
Kemi Anthony Emina \\ Department of Religious Studies and Philosophy, Delta State University, Abraka, Delta State, Nigeria \\ Email: eminakemi@yahoo.com
}

\begin{abstract}
:
This article examines the elusive search for peace in a plural Society in Africa, amid persistent ethno-religious conflicts and violent attacks in eminent. The central thesis of this article focused on why existing theoretical perspectives on the nature and management of ethnoreligious conflicts in Africa have disappointed expectations, and what is required to achieve peace among plural African societies. This article used Nigeria as a case study. The research argues that conflict resolution has an ontological dimension and that achieving peace in plural societies requires a process of genuine orientation that reworks the human consciousness to accept the inevitability of the 'Other' both to the self and its aspirations for survival. This research employs the method of textual and critical analysis in carrying out this research.
\end{abstract}

\section{Keywords:}

ethnicity; plural societies; religion; conflict; Africa

\section{Introduction}

The modern African States are laced with highly insidious and obstinate conflicts (Ogar et al. 2019). A critical focus on these lethal schisms suggests religious differences and ethnic sentiments as leading causal factors. In Nigeria, Somalia, Uganda, Cameroon, Niger, Kenya, and several other African States, ethnoreligious conflicts obscure peace, challenge development prospects and pulverize human and material resources.

Whereas the communitarian structure and the emphasis on cultural identity in Africa make ethnicity an important cultural condition, the spirituality of the African makes religion a culturally viable and indispensable phenomenon (Bassey \& Pimaro 2019). Interestingly, these important aspects of identity are not exclusive packages of the African person. As Olatunji Oyeshile notes, while religion is a global phenomenon, ethnicity itself is as primordial as human evolution since people are born into specific cultures within certain political and geographical spaces (Oyeshile, 2005: 10).

While every human being has an ethnic identity and a religious inclination, the African ethno-religious experience is compelling for several reasons. First, religious and ethnic particularities are the most politically and socially vibrant forms of identity in Africa. Thus, whether in our competitive or non-competitive contexts, we invoke ethnic and religious demarcations to assert our identity. Second, there is a general propensity to distribute privileges and develop relationships based on religious and ethnic compatibilities. Third, there is the tendency to elect the interest of some ethno-religious groups in ways that undermine the interests of others and assert the values of certain ethnicities and religious organisations as legitimisation models for religious and social correctness. Hence, this paper argues that while the use of religion and ethnicity as forms of identity and authenticity seems less disruptive, these human elements can act as springboards for material and human destruction when applied to discriminate, extract privileges, usurp, and dominate the interest of others in a 
multicultural or plural society. Achieving peace, thus, requires the promotion of the values of solidarity, intersubjectivity, complementarity, and togetherness. It is this way of managing a multicultural relationship that makes the existentialist ethic of impersonal relations which focuses on the cogito, I, the ego, the human consciousness, an indispensable tool for conflict resolution, and peaceful existence among the various ethnic and religious groups in Africa.

\section{Review of Literatures}

\subsection{On the Notions of Ethnicity, Religion, and Plural Societies a. Ethnicity}

Ethnicity, as a concept, attracts different interpretations. Max Weber uses the term to refer to human collectives who entertain a subjective belief in their common descent because of similarities of a physical character, or of customs or both, or because they share common memories about colonisation or migration (Weber, 1968: 389). Richard Schermerhorn construes an ethnic group as a "collective within a larger society who have a real or putative common ancestry, memories, or shared historical past, and a cultural focus on one or more symbolic elements defined as the epitome of their peoplehood" (Schermerhorn, 1970: 12). Schermerhorn uses "symbolic elements" to refer to physical contiguity, kingship patterns, tribal affiliation, language or dialect, phenotypical features, and nationality. For this research, we understand an ethnic group to refer to a population that:

1. Shares basic cultural values

2. are largely biologically self-preserving

3. has a membership which sees itself and is understood by others as making up a distinguishable category from other categories of the same order

4. makes up a field of communication and interaction.

\section{b. Religion}

Adeniyi (1993) defines religion as a body of laws, rites, and truth through which the human person is subordinated to a supernatural being. Hence, religion involves spiritual principles, beliefs, and rules from a transcendent being which are expected to be obeyed by believers. Ayinla (2003) presents religion as a particular system or a range of systems in which rituals, doctrines, sentiments, and myths among other similar elements, are interrelated.

According to Elizu (1993), religion is the human person's intuition about a divine, sacred, and ultimate reality, and the person's demonstration of this awareness in practical life. Horton (1960) and Gordon (1961) accept the notion of religion as a sacred enterprise that suggests a transcendental being. Peter (1998) construes religion as a system of symbols that aims to institute pervasive, powerful, and subsisting motivations and moods in people by developing conceptions of a general order of existence and covering these notions with an aura of factuality in ways that make the moods and motivations uniquely realistic.

Emile Durkheim presents religion as a unified system of beliefs and practices relative to sacred things. Durkheim believes religion involves certain practices, ways of thinking, and beliefs unique to such institutions. The Oxford Dictionary interprets religion as "one of the systems of faith that are based on the beliefs in the existence of a particular God or gods." The Oxford Learners' Dictionary defines it as the belief in a supernatural being controlling power and is entitled to worship and obedience. 
Contrary to suggestions that religion has lost its relevance in the modern affairs of the State (see Rostow, 1959, Apter 1965, Smith, 1970), religion has subsisted over time as an important cultural, economic and political element. Huntington (1993) recounts how religion and its cultural structures are important drives of modern culture and global politics. In politics, we identify religion with the ability to undermine or bolster political legitimacy (Fox and Sandler 2003, p562). Hence, religion acts as one of the main instruments that legitimise or illegitimate political regimes (Nasr, 1998; Haynes, 1994.) This occurs mostly in places where religious lineages or affiliations can be invoked to impact political outcomes, and where there is diversity in the religious population.

The above suggests religion as an important element of ethnicity and a significant source of identity which informs the basis of acrimony and discord among groups in a particular nation. Fox (1997:5) emphasises this point when he argues that "religion is salient if it is a defining trait that sets a group apart." Similarly, it is salient if it expresses the capacity to shape all forms of a group's social and political activities (Fox \& Sandier, 2003: 568). Hence, religion can be explored to discriminate against other nationalities and religious groups. According to Fox (1999), upon perceived discrimination or threat to the survival of religion, religious institutions can mobilise for protest or rebellion (Fox, 1999, p135). This becomes more compelling when a religious group explores force as an option to defend its principles or values (Fox \& Sander, 2003:.566). Hence, religious practices have a strong connection to situations of violence.

\section{c. Plural Societies}

There is a wide difference of opinion about an acceptable definition of a plural society. This current conceptual predicament is akin to the 1961 experience that led R. T. Smith to explain the term as "one of those words... that everybody understands in a general way, but few people would care to define precisely." For this study, we accept J.S. Furnivall's definition of a plural society as "one comprising two or more elements of social order which live side by side within the same political unit without mingling." These elements of social order include customs, values, and race (R. T. Smith 1958).

Plural societies, thus, contain ethnic and racial groups and are characterised by the operation of certain shared values. A plural society does not merely suggest that ethnic and racial dissimilarities often characterise social situations or societies, but that these dissimilarities are significant in understanding other patterns of behaviour. According to Cross (1971), these plural structures, under some circumstances, are the major determining factor in social organisation. Plural societies, therefore, contain "racial and ethnic groups and are characterised by a 'minimum of common values' and by sharp cleavages between (these) different population groups brought together within the same political unit."

\section{Discussion}

\subsection{Ethno-Religious Conflicts in Africa: Cases from Nigeria}

Ethno-religious conflicts "refer to those involving groups where religion is an integral part of social and cultural life, and religious institutions are representative, possess moral legitimacy, and mobilisation potential" (Orellana, 2009: 264-280). In Nigeria, for example, ethno-religious conflicts have risen since the 1980s. Consider the 1980 Maitastine riot in Kano and Borno States that caused the death of at least four thousand people. According to a report by the Havard Divinity School:

The Maitatsine riots were a series of violent uprisings instigated by Islamist militants in northern Nigeria between 1980 and 1985 and represented northern Nigeria's 
first major wave of religiously inspired violence. The riots prompted immense ethnoreligious discord between Muslims and Christians in years to come (Harvard Divinity School).

Other cases include the Kafanchan crisis of 1987, which occurred at the Kafanchan College of Education over a crusade organised by Christian members of the College. The crisis spread to Funtua, Zaria, and the Kaduna metropolis. At least twenty-five (25) people were killed, and they destroyed properties. In 2001, ethno-religious conflicts between the Hausa and the Ibo displaced over Five Hundred Thousand people (Isiramen, 2010). These attacks happened in Onitsha, Anambra State.

Boko Haram's violent insurgency in Nigeria, which began in 2009, has led to over 20,000 deaths as of 2018 (Wilson, 2018). Although the Nigerian media, including foreign sources, translate Boko Haram as "Western education is forbidden" (Vanguard, 2018), an official statement from Boko Haram contradicts this interpretation:

Boko Haram does not mean 'Western Education is a sin' as the infidel media continue to portray us. Boko Haram means 'Western Civilisation' is forbidden. The difference is that while the first gives the impression that we are opposed to formal education coming from the West... which is not true; the second affirms our belief in the supremacy of Islamic culture (not Education), for culture is broader, it includes education but not determined by Western Education (Onouha, F.C. 2012).

Boko Haram thus frowns at the media description of it as Boko Haram. Instead, it prefers to be addressed as the Jama'atu Ahlissunnah Lidda'awati Wal Jihad, meaning a "People Committed to the Propagation of the Prophet's Teachings and Jihad" (Onouha, F.C. 2012). As Aljazeera, a global news outlet, notes, "Although the sect's name has changed over the years, its ideological mission is clear, namely to overthrow the Nigerian state and impose strict Islamic Sharia law in the country" (Onouha, F.C. 2012).

A plethora of commentaries suggests Boko Haram, a religious configuration, has ethnic colourations, and that it is used to facilitate an ethnic agenda. Many interlocutors on the foundational motivations of Boko Haram believe the Hausa/Fulani group use Boko Haram to extract political and economic gain to the detriment of other ethnic nationalities. Conspiracy theories accusing Northern politicians of sponsoring insurgency in the north to make the country ungovernable for political actors from other regions have driven political calculations during election periods. In 2015, for example, there were allegations that the Northern Muslims were using Boko Haram to frustrate and destabilise the national government led by a Southern Christian. Brookings' report on the emergence of Boko Haram explains better:

This theory is very popular among commentators and leading politicians from the southern part of the country. President Jonathan is a southerner from the minority Ijaw ethnic group. According to the theory, people from the north, essentially the "core north" (that is, the Hausa/Fulani), believe it is their birthright to govern the country, and because a Christian southerner is in charge, they sponsored Boko Haram as an instrument for destabilising the Jonathan presidency (Adibe, 2014).

A counter-theory suggests Boko Haram is funded and sustained by the Southerners to depopulate the region and mobilise support for the government of a southern Christian. The report explains further:

Another conspiracy theory is that Boko Haram is usually sponsored by the Jonathan administration to make Islam look bad or give the impression that the north is out to pull down his administration ... A variant of this theory is that Boko Haram is 
sponsored by the government to weaken, destroy or reduce the population of the north ahead of the 2015 elections...leaders from the north, including the governor of Adamawa, Murtala Nyako, and governor of Sokoto State, Alhaji Aliyu Wammakko, have legitimised this theory by coming out to subscribe to it openly (Adibe, 2014).

Obvious incongruities with these theories are not our concern. Our point is that, although these views are mere conspiracy theories, they have impacted ethnic and religious relationships between the people of the North and the South. The theories have also established the fluidity of ethnic and religious conflicts, especially how these strands of discord facilitate each other.

There is an ongoing ethnic conflict between the Tiv and the Fulani in Nigeria's north region. Although the conflict is believed to be farmers versus herders' crisis, there are strong claims that the conflict is an attempt by the Fulani to actualise a failed project of territorial usurpation and ethnic cleansing attempted by Usman dan Fodio during the great Jihad against the people of Benue and their valley. Mr Terver Akase, the Chief Press Secretary to the Benue State Governor, claimed during an interview with the Punch Newspaper in December 2018 that "the agenda to take over Benue State by the Fulani is still there. They have not given up." Similarly, a former commissioner in the State, Honourable Rebecca Apedzam, in an interview published by the Vanguard Newspaper in May 2018, claimed that the crisis is aimed at usurping the Benue valley from its indigenous ethnicities. According to Apedzam:

The truth is that it is all about land, Fulani herdsmen want to sack us from our

land. They had said it before that they wanted the Benue Valley which they said was their ancestral land... whenever they attacked, they destroyed all the houses, burnt down others so that nobody could stay there which they would then occupy (Vanguard, 2018).

The Fulani have claimed that grazing is a cultural phenomenon and that grazing through Benue had no specific aims beyond the expression of their traditional obligations towards their culture. Apart from these crises, there are ethno-religious conflicts between the Itsekiris and Ijaw, Igbo versus the Hausa, Yoruba versus the Fulani, among others. Such conflicts have brewed pressure groups and ethnic militias such as the Niger Delta youths and the Egbesu boys in the South-South, the Odua People's Congress (OPC) and Afenifere in the South-West, The Arewa People's Forum and the Northern Elder's Forum in the North, Ohaneze Ndigbo, in the South-East, Christian Association of Nigeria, and Muric, to mention a few. These groups have pursued a wide range of interests including power and resource control, the exercise of religious rights, the entrenchment of religious legal systems, control over territory, oil derivation, privatisation, and revenue distribution among others.

\subsection{The Causes of Ethnoreligious Conflicts in Africa.}

Several theories explain the causes of ethnic conflicts in Africa. These theories share the common understanding that the struggle for economic control and political power causes ethnic conflicts. There are also two main perceptions of the causes of religious conflicts in Africa. Others explain ethnic attachments and historical divisions in religious ideologies as causes of religious conflicts in Africa. This research identifies ethnocentric tendencies as the major causal factor responsible for the ethnic and religious crisis. Ethnocentric tendencies motivate the will to legitimise and elevate one's interest above the interests of others and without considerations of their rights to certain forms of expression. It is, in simple terms, the tendency to elect the values, beliefs, aspirations, and goals of the self, or the group, above and beyond the interest of others. 
To create a better understanding of how ethnocentric commitments form conflicts, let us consider Ortega Y'Gasset's discussion of what has exposed Europe to the greatest crisis that can afflict people, nations, and civilisations. In his Revolt of the Masses, Y'Gasset recounts an interesting story about the rise of the senerito satisfecho (Y'Gasset, 1930: 66-75) (the satisfied young man or Mr Satisfied), the specialist in Europe who believes he has it all and extends the command he has of his subject to others, contemptuous of his ignorance in all of them. The senerito satisfecho differs from the "common" man of all periods because for the "common" man, life had principally meant limitation, obligation, and dependence (Y'Gasset, 1930: 66-75) The senerito satisfecho has these psychological attributes towards public life:

(1) An inborn, root-impression that life is easy, plentiful, with no grave limitations; each average man finds within himself a sensation of power and triumph which, (2) invites him to stand up for himself as he is, to look upon his moral and intellectual endowment as excellent, complete. This contentment with himself leads him to shut himself off from any external court of appeal, not to listen, not to submit his opinions to judgment, not to consider others' existence. His intimate feeling of power urges him always to exercise predominance. He will act then as if he and his like were the only beings existing in the world and, (3) will intervene in all matters, imposing his vulgar views in respect or regard for others, without limit or reserve by a system of "direct action" (Y'Gasset, 1930: 68).

A look at Ortega's senerito satisfecho shows that the main problem of Europe is the radical elevation of individualism and ethnocentrism (Bassey, 2016). Interestingly, it is not only Europe that is experiencing its worst crisis because of the rise of Y'Gasset's poetic selfsatisfied, notoriously individualistic man. Ethnic and religious sentiments based on the wrongheaded assumption that a particular ethnic or religious group is superior in values and leadership, hence, such a group must dominate and control all others, regulate economic and political benefits, including the administration of human and natural resources, have brewed conflicts in Africa. Thus, in Nigeria, Somalia, Burundi, Sudan, Congo, Liberia, Libya, Rwanda, Cameroon, Niger, Liberia, the Gambia, and other African states, one notices intense religious and ethnic conflicts because of an attempt to legitimise, elevate and impose the interest of the domineering group over others.

Although ethno-religious conflicts operate in Africa under different labels and pretensions, an essential motivation that runs through all of them is the desire to actualise the innate urge to put their interest first at the cost of other stakeholders (Ikegbu et al. 2009). Another motivation routes from their desire to address imbalances in asymmetrical power situations, as those who have the advantage of power feel obliged to utilise it to achieve specific objectives. These motivations have inspired prejudices between the group that aspires to dominate and the group that feels dominated.

In 'The Nature of Prejudice', G.W Allport identifies five features likely to be displayed by a prejudiced person towards another. These include:

1. One, negative remarks: the subjects speak despairingly about groups they dislike

2. Two, avoidance: the prejudiced subjects avoid those who are not part or members of the group

3. Three, discrimination: the prejudiced group malign the other insignificant aspects, including employment, social privileges, places of residence among others

4. Four, physical attack: the prejudiced subject becomes violent, and embraces violence to intimidate those outside his group.

5. Extermination: the prejudiced person takes part in massacres, lynching, extermination 
programmes among others (Awake! Sept. 8, 2005:5)

These features are the most obvious contours of ethno-religious conflicts in Africa.

\subsection{An Existentialist Solution to Ethnoreligious Conflicts in Africa}

Efforts to resolve ethno-religious conflicts and establish peace among the various religious and ethnic groups in Africa have either failed to achieve lasting solutions or outrightly disappointed expectations. This is because these efforts focus on the legalistic and mechanical approaches to conflict resolution. By legalistic approaches, we mean laws enacted to compel behaviour in certain ways that benefit the interest of certain groups. Mechanical approaches, as used here, are military and paramilitary efforts. While these instruments are vital for order, regardless of the status of the society, they are grossly inadequate when building sustainable approaches to peace in plural societies. Apart from escalating descent and perpetuating economic, material, and human waste, mechanical approaches to peace influence a culture of historical revenge, disdain, and hate.

Legalistic efforts summarily restore order between two dissenting parties without addressing the core issues responsible for the acts. Consider the Anti-grazing bill enacted by the Benue State government to quell attacks and invasion by the Fulani's, for example. While the bill has reduced the level of attacks, it is unclear whether the bill has addressed the main contentions of the conflict, especially the claim by the State Government that there is a historical desire by the Fulani to usurp and convert the Benue valley to their ancestral land. It is also unclear whether the bill has changed the attitude of the mind that seeks the usurpation. It is the gap between legalistic and mechanical approaches on the one hand and the attitudes of the mind that brew these conflicts on the other that makes the existentialists' philosophy of intersubjectivity an important response to ethno-religious conflicts and our quest for peace in plural African societies.

The existentialist model, which emphasises the position of the self, the ego, the I, in conflict generation and resolution, is important for some reasons. First, the various actors are self-centred, perhaps in pursuit of a spurious authenticity, or a natural inclination to selfpreservation. This reason seems similar to the existentialist project of subjectivity in which the pour-soi, the cogito, claims a central role and place in the world. Second, religious and ethnic groups exclude others in pursuing their goals and distributing welfare. This undermines the existentialist notion of intersubjectivity which emphasises belonging together and care for being. Third, conflicts are ontological. They are inevitable outcomes of concrete human relationships. Unah (2000) emphasises this point when he writes that: "Generally, conflicts do not occur in a Robinson Crusoe situation. They occur from social relatedness. Insofar as we are human beings living in human society, conflicts cannot but occur" (Unah, 2000: 237).

Unah's argument underscores the inevitability of conflicts at the interpersonal level. The most significant issue, therefore, is how to manage conflicts. But it is unlikely to manage conflicts without considering the actors, without considering the position of the intersubjective egos. This makes the existentialist ethics of intersubjectivity, which promotes and provides the ontological and moral basis for group solidarity, complimentary relations, independence, and mutuality, significant to our quest for peace in Africa.

With the growing complexity of plural societies, and their differences in historical, cultural, economic, political and social values, plural societies are prone to antagonism, hate, discrimination, tensions and crisis (Jamieson, 2004:373). The tendency to assert self-identity and demand self-determination by marginalised groups is one outcome of the interaction of differences in plural societies. The challenge for peace in plural African societies, therefore, 
seems to be the lack of knowledge of an ontological and moral basis for belonging together and caring for the other.

The question is, how does existentialism solve this challenge? In his Being and Nothingness, Sartre writes that "I cannot get any truth about myself except through the mediation of another. The other is indispensable to my existence and equally so to any knowledge I can have of myself. Heidegger shares the same sentiment by construing Being as the possibility of understanding oneself, as linked to the ethical practice of Being-in-the-world. Buber says we take our stand in relation (Vogel, 1970). Hence, we achieve authenticity by acknowledging our being in others as beings-in-the-world. Jim Unah explains the depths of this interdependency:

The awareness of the being of others is part of the awareness of our being and implied in it as a teacher implies the pupil, and the taxi-car implies both the driver and the passenger. We discover ourselves as existing with other people and our being as being with others (1996: 60).

The relevance of these imports is that they provide a veritable ontological and ethical foundation for group solidarity and understanding needed to overcome conflicts and achieve peace in plural African societies, which is lacking. It emphasises that as individuals and groups, our survivor is tied to the survivor of others and that we must acknowledge the other not as means to the achievement of certain objectives, or as actors standing in our path of selfactualisation or progress, but as human beings with ends in themselves who are indispensable and inescapable in our project of survival. When the citizens are educated and reoriented to accept that the existence of the other is indispensable to the 'my' existence, and that the other is also an end and not a goal for the achievement of one's selfish desires, then foundational peace across groups, social progress, economic growth and a genuine culture of nationalism would emerge.

Existentialism does not emphasise complementary relations alone. Existentialists see the self as a realm of commitment and responsibility. Sartre, for instance, writes that "man first of all exists, encounters himself and surges up in the world and defines himself afterward." Heidegger writes that responsibility is not just for the self, but also for the Other. Buber sees "responsibility as the stuff of which the I-Thou relation is made" (Vogel, M. 1970: 164.) In Between Man and Man, Buber writes that "the saying thou (not I) stands in the origin of all individual human beginning" (Buber, 1947: p249). The authentically realised being is being in relation, specifically, the I-Thou relation (Vogel, M. 1970). Buber says we "take our stand in relation."

The importance of these imports is that they supply the ontological, moral, and epistemic justification for intercultural dialogue, exchanges, and relationships. They also undermine the very pretentions of ethnocentrism that provoke ethnoreligious conflicts. What is therefore required is a process of genuine orientation that reworks the human consciousness to accept the inevitability of the Other both to the self and its aspirations for survival. Oladipo corroborates this when he writes that "what is required for the renewal of hope in Nigeria as a viable modern state is the establishment of an appropriate framework for mutual cooperation among the various nationalities in the country" (Oladipo, 2000: 64-68) It is this framework that the existentialist principle of intersubjectivity provides. There is also the need to restructure our social institutions in such a way that they become an effective vanguard in the promotion of civic values of tolerance, dialogue, understanding, compassion, justice, and equity. 


\section{Conclusion}

Almost all African countries have specific development goals and targets. Unfortunately, the rise of ethnoreligious conflicts on the continent have undermined these efforts and obscured the prospects of materialising these development ambitions. Our study focused on why existing theoretical perspectives on the nature and management of ethnoreligious conflicts in Africa have disappointed expectations, and what is required to achieve peace among plural African societies. The research argues that conflict resolution has an ontological dimension and that achieving peace in plural societies requires a process of genuine orientation that reworks the human consciousness to accept the inevitability of the Other both to the self and its aspirations for survival.

\section{References}

Adeniyi, M.O. (1993). "Religion and Politics: An Eye Bird's View of Development in Nigeria". In: Abubakar RD (ed.) Religion and Politics in Nigeria Ilorin: NASR.

Adibe, J. (2014). Explaining the Emergence of Boko Haram. Brookings. Retrieved via: https://www.brookings.edu/blog/africa-in-focus/2014/05/06/explaining-theemergence-of-boko-haram/ Retrieved January 20th, 2020

Apter, D. (1965). The politics of modernization. Chicago, Ill.: University of Chicago Press.

Asouzu, I. (2011). "Ibuanyidanda" and the Philosophy of Essence. Calabar: University of Calabar Press.

Ayinla, S.A. (2003). "Managing Religious Intolerance and Violence in Nigeria, Problems and Solutions. A Paper Presented at the National Conference on Social Problems, Development and the Challenges of Globalization, Organized by Department of Sociology and Anthropology, Obafemi Awolowo University Ile-Ife.

Bassey, S. A. (2016). Democracy and Gasset's 'The Revolt of the Masses': An Exposition. OmniScience: A Multi-disciplinary Journal, 6(2), 1-8.

Bassey, S. A., \& Pimaro Jr, T. M. (2019). Enyimba's Notion of Madukaku and The Question of Anthropocentricism In African Environmental Ethics.

Cross, M. 'On Conflict, Race Relations, and the Theory of the Plural Society.' RACE, XII, no. 4, April 1971, pp. 477-494.

Ejizu, C.J. (1993). Religion and Politics in Nigeria: The Perspective of the Indigenous Religions. In Abubakre RD et al (eds.) Religion and Politics in Nigeria.

Fox, J. (1999). "Do religious institutions support violence or the status-quo?." Studies in Conflict \& Terrorism, 22 (2), 119-139.

Fox. J \& Sandler, S. (2003). "Quantifying religion: Toward building more effective ways of measuring religious influence on state-level behaviour." Journal of Church and State, 45 (2), 559-588.

Fox. J \& Sandler, S. (2003). "Quantifying religion: Toward building more effective ways of measuring religious influence on state-level behaviour." Journal of Church and State, 45 (2), 559-588.

Goody J.R. (1961). "Religion and Ritual; The Definitional Problem." British Journal of Sociology, 14: 82-91.

Havard Divinity School. "Maitatsine Riots." Religious Literacy Project. Accessed via: https://rlp.hds.harvard.edu/faq/maitatsine-riots retrieved January 20th, 2020.

Haynes, J. (1994). Religion in third world politics. Colorado: Lynne Rienner Publishers.

Horton RF (1960). "A definition of Religion and its Uses." J. Royal Anthropological Institute., 87: 370-383.

Huntington, S. (1993). “The clash of civilizations?.” Foreign Affairs, 72 (3)22-49. 
Ikegbu, E. A., Ogar, J. N., \& Inyang, J. O. (2009). Nigeria's ethnic diversity and its proneness to conflict and violence. Ndunode: Calabar Journals of the Humanities, 8, 109-182.

Isiramen, C .O. (2010). "Religious crisis and development in Nigeria" in Isiramen, C .O, Imaekhai F.J. and Igboin B.O. (eds) Religion and the Nigerian Nation: Some topical issues. Ibadan: Enjoy Press \& Books.com/amar/pdf/parish.pdf

Kadayifci-Orellana, S. A., (2009). "Ethno-Religious Conflicts: Exploring the Role of Religion in Conflict Resolution.” J. Bercovitch, V. Kremenyuk, and I. W. Zartman (eds.) The SAGE Handbook of Conflict Resolution. SAGE, London.

Nasr, V. (1998). Religion and global affairs: Secular states and religious oppositions. SAIS Review, 18 (2), 32-37.

Ogar, J. N., Nwoye, L., \& Bassey, S. A. (2019). Archetype of globalization: illusory comfort of neo-colonialism in Africa. International Journal of Humanities and Innovation (IJHI), 2(3), 90-95.

Oladipo, O. 2000. "Values and National Rebirth." Recall: A Chronicle of Nigerian Events, No 1: $64-68$.

Olatunji, O.A. 2005. Reconciling The Self With The Other: An Existentialist Perspective on The Management of Ethnic Conflicts in Africa. Ibadan: Hope Publishers.

Onouha, F.C. 2012. "Boko Haram: Nigeria's Extremist Islamic Sect." Aljazeera center for studies. Retrieved via: http://studies.aljazeera.net

Onouha, F.C. 2012. "Boko Haram: Nigeria's Extremist Islamic Sect." Aljazeera center for studies. Retrieved via: http://studies.aljazeera.net

Peter, O.F. (1998). "Plateau Crisis Claimed 54,000 Lives" The Cities of Perpetual Public Work. Accessed via: www.amarujari Retrieved January 20th, 2020.

Rostow, W. (1959). The stages of economic growth: A non-communist manifesto. Cambridge: Cambridge University Press.

Schermerhorn R (1970) Comparative Ethnic Relations. New York: Random House.

See Vanguard Newspapers. Boko Haram: From Islamic Sect to deadly armed group. Accessed via: https://www.vanguardngr.com/2015/06/boko-haram-from-islamic-sect-todeadly-armed-group/ Retrieved January 20th, 2020.

Smith, D.E. (1970). Religion and political development. Boston, Massachusetts: Little, Brown.

SMITH, R.T. "Review of Social and Cultural Pluralism in the Caribbean." American Anthropologist, 63, 1961, pp. 155-157.

Unah J.I. (2000) "Difficult Decision Situations: A Phenomenological Ontology of Crisis Management." A.T. Tymienieke (ed.), Anelecta Husserlianam, LXVIII: 237-246

Vanguard Newspapers. Boko Haram: From Islamic Sect to deadly armed group. Accessed via: https://www.vanguardngr.com/2015/06/boko-haram-from-islamic-sect-to-deadlyarmed-group/ Retrieved January 20th, 2020.

Weber M (1968) Economy and Society, ed. Roth G, Wittich C. Berkeley: University of California Press.

Wilson, M. 2018. "Nigeria's Boko Haram attacks in numbers - as lethal as ever." BBC Monitoring. Retrieved through https://www.bbc.com/news/world-africa-42735414. Accessed January 20th, 2020. 